\title{
Primary Care Centers Pharmacist Workforce Demand in Eleven Years (2006-2016), and Forecasting in Fifteen Years (2016-2030) at Ministry of Health in Saudi Arabia
}

\author{
Yousef Ahmed Alomi ${ }^{1 *}$, Saeed Jamaan Alghamdi², Radi Abdullah Alattyh ${ }^{2}$ \\ ${ }^{1}$ The Past General Manager of General Administration of Pharmaceutical Care and The Past Head, National Clinical pharmacy, \\ and pharmacy practice and Pharmacy $R$ and D Administration, Ministry of Health, Riyadh, KSA. \\ ${ }^{2}$ General Administration of Pharmaceutical Care, Ministry of Health, P.O.BOX 100, Riyadh 11392, Riyadh, KSA.
}

Received: 13 December 2017;

Accepted: 28 February 2018

*Correspondence to:

Dr. Yousef Ahmed Alomi,

The Past General Manager of General Administration of Pharmaceutical Care, The Past Head, National Clinical pharmacy, and pharmacy practice, Head, Pharmacy $R$ and $D$ Administration, Ministry of Health, P.O.BOX 100, Riyadh 11392, Riyadh, Saudi Arabia.. Email:yalomi@gmail.com

Copyright: () the author(s),publisher and licensee Indian Academy of Pharmacists. This is an open-access article distributed under the terms of the Creative Commons Attribution Non-Commercial License, which permits unrestricted non-commercial use, distribution, and reproduction in any medium, provided the original work is properly cited.

\begin{abstract}
Objective: The aim of this study is to explore primary care centers pharmacist workforce demand in eleven years (2006-2016) and projection of primary care center pharmacists demand for coming fifteen years (2016-2030) at Ministry of Health in Saudi Arabia. Methods: It is a retrospective analysis of eleven years (2006-2016) of MOH primary healthcare center (PCC) pharmacist's workforce demand and projection of primary care center pharmacist's demand for coming fifteen years (2016-2030) at Ministry of Health in Saudi Arabia. All data were derived from Ministry of Health Statistical Year Books over the past eleven years and Ministry of Health (MOH) standard. It included demand pharmacists or clinical pharmacists' workforces at $\mathrm{MOH}$ primary healthcare centers. All calculations were based on Ministry of Health workforce standards of primary healthcare center. The calculations were per each region for a total of twenty-one regions, the primary health care center distribution numbers, the ratio of pharmacist per PCC, total number of demand pharmacist per each PCC, the expected number of pharmacist requirement in the coming years 2016-2030, primary healthcare center Pharmacist per each region across Saudi Arabia. Results: The total numbers of hospitals were 276 hospitals, 2,325 primary care centers, and 20 administration regions. The total numbers of pharmacists were 3,520 distributed at hospital 2,760 (78.41\%), at primary care centers 430 (12.2\%) while administration regions $330(9.37 \%)$. The average number of pharmacist per each primary care center pharmacist was $(0.077)$ with a range number of $(0.035-0.195)$. The total average demand primary care center pharmacists were $(10,617.18)$ with range $(9,586-11,401)$ with total number demand was $(11,401)$ primary care center pharmacist. The total demand pharmacists for primary care centers by the year 2030 will be $(16,515.79)$ with range $(11,625.00-16,515.79)$. Conclusion: Over past several years, there was very high demand of primary care pharmacist in Saudi Arabia. There is a high number of pharmacist jobs in the future. Targeting of implementation of Saudi Vision 2030 including pharmacy new vision are highly recommended in Kingdom of Saudi Arabia.
\end{abstract}

Key words: Parenteral nutrition, Pharmaceutical care, Ministry of health, Saudi arabia.

\section{INTRODUCTION}

The pharmacist role at Primary health care centers is critical. The American Society of Health-System identified the Pharmacist duties during practice at primary healthcare centers. ${ }^{[1]}$ All primary care center expected to implement the concept of pharmaceutical care, pharmacy strategic planning, and Saudi Center forHealthcare accreditation. ${ }^{[1-3]}$ Several studies investigated pharmacist workforces and other studies reported the demand pharmacy staff either currently or in the future. Those studies conducted in different countries ${ }^{[4-15]}$ However, it very hard to find any investigations about primary care center demand analysis and projection of pharmacist in the future in the Kingdom of Saudi Arabia or Gulf, Middle East countries and even vast world countries. ${ }^{[6,16]}$ The objective of this study is to explore the pharmacist demand in primary healthcare centers currently and projection of the future demand in Saudi Arabia.

\section{METHODS}

It is a retrospective analysis of eleven years (2006-2016) of MOH primary healthcare center (PCC) pharmacist workforce demand and pharmacist projection for coming fifteen years (2016-2030) at Ministry of Health in Saudi Arabia. All data were derived from Ministry of Health statistical Year Books over the past eleven years and Ministry of Health standard. ${ }^{[17-27]} \mathrm{It}$ included a demand pharmacist or clinical pharmacist's workforces at $\mathrm{MOH}$ primary healthcare centers. The type of PCC levels services included in the studies. All type of pharmacy services based on Saudi Central Board of hospital accreditation, a Joint Commission of Hospital Accreditation, American Society of Health-System best practice standards, and general administration of the pharmaceutical care strategic plan. ${ }^{[28-32]}$ All Pharmacists who works at $\mathrm{MOH}$ hospitals or administration or non-MOH government hospitals and primary care centers were excluded from the studies. All private hospitals or community pharmacists were excluded from the study. All pharmacy technicians were excluded from the study. All calculations were based on $\mathrm{MOH}$ workforce standards of primary healthcare center and expected incremental population in Saudi Arabia. The calculations were per each region for a total of twenty-one regions, the primary health care center distribution numbers, the ratio of pharmacist per PCC, total number of demand pharmacists per each PCC, the expected number of 
pharmacist's requirement in the coming years 2016-2030 primary healthcare center Pharmacist per each region overall Saudi Arabia. All calculations were done used Microsoft Excel version ten.

\section{RESULTS}

The total numbers of hospitals were 276 hospitals, 2,325 primary care centers, and 20 administration regions. The total numbers of pharmacists were 3,520 distributed at hospital 2,760 (78.41\%), at primary care centers $430(12.2 \%)$ while administration regions $330(9.37 \%)$ the last update information October 2016 as explored in Table 1. The average number of pharmacist per each primary care center was $(0.077)$ with a range number of (0.035-0.195. The region had highest number of pharmacist per each primary care center was Riyadh (0.196) followed by Jeddah (0.155) and Makkah regions $(0.128)$ as explored in Table 2 . The total average demand primary care center pharmacists were $(10,617.18)$ with range $(9,586-11,401)$ with total number demand was $(11,401)$ primary care center pharmacists. The high demand of primary care center pharmacists was in Riyadh regions $(2,006)$ followed by Asser regions $(1,227)$ and Jazan region $(886)$. The total demand pharmacists for primary care centers by year 2030 will be $(16,515.79)$ with range $(11,625.00-16,515.79)$ as explored in Table 3 and Table 4.

\section{DISCUSSION}

Over the past years, there are some new models of primary healthcare services established during healthcare strategic plan of Ministry of health in Kingdom of Saudi Arabia. The implementations consisted of new building of ambulatory care clinic with medical and surgical services and sometimes add to the emergency department. In addition to supporting services including pharmacy services, laboratories service, and radiology department. [27] All those sections need healthcare Human Resources with enough qualities and quantities. The pharmacy administration updated several things including PCC pharmacy Skelton, PCC pharmacist competencies, and national pharmacy practice and pharmacy administration programs. $[2,33-35]$ The pharmacy workforce established released new guidelines for the workforce in 2014-2015 with a number of a pharmacist and added clinical pharmacist. The question raised by the many pharmacist demand to cover all PCC pharmacies. The authors calculated the pharmacy workforce's demand in the current year and coming future years. The finding showed the average rate of pharmacist per primary care centers is very far from the $\mathrm{MOH}$ standards with a vast number of a number of pharmacist requirement over the past several years ago. The demand of pharmacists is increased with increased number of primary care centers without much addition or increase of new pharmacist, thus with several years, there was a cumulative high requirement. The best solution to meet the pharmacist demand is to start implementation of Saudi Managed Care Pharmacy. It will meet more than ninety percent of pharmacist requirement at primary care centers. The excepted pharmacist demand at primary care centers was not well investigated. Two studies by Bond CA et al., and Knapp DA calculated the pharmacist's projection in the future based on their functions or duties and sites but the primary care centers were not mentioned. ${ }^{[6,16]}$ The projection of a number of primary care center pharmacist over fifteen years will expand the problems of employment. The best solution is full implementation of Saudi Vision 2030 with the emphasis on privatization and apply the new vision of

\begin{tabular}{|c|c|c|c|c|c|c|}
\hline & Region & $\begin{array}{l}\text { No of } \\
\text { Hospitals }\end{array}$ & $\begin{array}{l}\text { No of } \\
\text { PCC }\end{array}$ & $\begin{array}{l}\text { No of Hospital } \\
\text { Pharmacist }\end{array}$ & $\begin{array}{l}\text { No of PCC } \\
\text { Pharmacist }\end{array}$ & $\begin{array}{l}\text { No of Pharmacist at } \\
\text { Directorates }\end{array}$ \\
\hline & $\mathrm{MOH}$ & 0 & 0 & 0 & 0 & 137 \\
\hline 1 & Riyadh & 42 & 418 & 497 & 117 & 37 \\
\hline 2 & Makkah & 10 & 84 & 230 & 14 & 19 \\
\hline 3 & Jeddah & 13 & 88 & 142 & 24 & 12 \\
\hline 4 & Taif & 13 & 121 & 90 & 9 & 8 \\
\hline 5 & Madina & 20 & 164 & 137 & 26 & 12 \\
\hline 6 & Quseen & 19 & 170 & 136 & 19 & 11 \\
\hline 7 & East Province & 20 & 136 & 169 & 21 & 11 \\
\hline 8 & Alhasa & 11 & 75 & 62 & 10 & 0 \\
\hline 9 & Heralbatin & 7 & 36 & 32 & 4 & 4 \\
\hline 10 & Aseer & 20 & 249 & 163 & 32 & 15 \\
\hline 11 & Bisha & 7 & 91 & 42 & 5 & 4 \\
\hline 12 & Tabouk & 11 & 77 & 66 & 9 & 3 \\
\hline 13 & Hail & 13 & 105 & 53 & 5 & 14 \\
\hline 14 & North Boarder & 9 & 46 & 40 & 3 & 9 \\
\hline 15 & Jazan & 21 & 159 & 128 & 11 & 5 \\
\hline 16 & Najran & 12 & 68 & 79 & 7 & 13 \\
\hline 17 & Albaha & 10 & 102 & 56 & 6 & 4 \\
\hline 18 & Aljouf & 9 & 37 & 38 & 1 & 5 \\
\hline 19 & Alqurayat & 4 & 18 & 22 & 2 & 2 \\
\hline \multirow[t]{2}{*}{20} & Qunfetha & 5 & 37 & 24 & 1 & 5 \\
\hline & Total & 276 & 2325 & 2760 & 430 & 330 \\
\hline
\end{tabular}


Table 2: Total number of pharmacist per PCC.

\begin{tabular}{|c|c|c|c|c|c|c|c|c|c|c|c|c|}
\hline & 2006 & 2007 & 2008 & 2009 & 2010 & 2011 & 2012 & 2013 & 2014 & 2015 & 2016 & Average \\
\hline Riyadh & 0.1634 & 0.2881 & 0.2095 & 0.0301 & 0.0050 & 0.1696 & 0.1701 & 0.1839 & 0.2799 & 0.3317 & 0.3278 & 0.196 \\
\hline Makkah & 0.0000 & 0.3108 & 0.2388 & 0.1310 & 0.0357 & 0.1429 & 0.0394 & 0.0652 & 0.1667 & 0.0964 & 0.1807 & 0.128 \\
\hline Jeddah & 0.3200 & 0.2800 & 0.0250 & 0.0430 & 0.0215 & 0.1183 & Missing Data & 0.0926 & 0.2727 & 0.2500 & 0.2778 & 0.155 \\
\hline Taif & 0.0096 & 0.0096 & 0.0000 & 0.0268 & 0.0000 & 0.0536 & Missing Data & 0.0250 & 0.0744 & 0.1250 & 0.1157 & 0.040 \\
\hline Madina & 0.0597 & 0.0299 & 0.1119 & 0.0350 & 0.0000 & 0.0769 & 0.0455 & 0.0519 & 0.1585 & 0.1358 & 0.1543 & 0.078 \\
\hline Quseen & 0.0282 & 0.1103 & 0.0000 & 0.0397 & 0.0000 & 0.0397 & 0.0126 & 0.0692 & 0.1118 & 0.1221 & 0.1130 & 0.059 \\
\hline East Province & 0.0982 & 0.1316 & 0.1190 & 0.0806 & 0.0242 & 0.1032 & 0.0363 & 0.0809 & 0.1544 & 0.1884 & 0.2429 & 0.115 \\
\hline Alhasa & 0.0000 & 0.0000 & 0.0000 & 0.0159 & 0.0000 & 0.0938 & Missing Data & 0.0000 & 0.1333 & 0.1507 & 0.2000 & 0.054 \\
\hline Heralbatin & 0.0000 & 0.0000 & 0.0000 & 0.0000 & 0.0000 & 0.1579 & Missing Data & 0.0000 & 0.1111 & 0.0750 & 0.1250 & 0.043 \\
\hline Aseer & 0.0000 & 0.0000 & 0.0000 & 0.0441 & 0.0000 & 0.0617 & 0.0252 & 0.0546 & 0.1285 & 0.2195 & 0.2450 & 0.071 \\
\hline Bisha & 0.0278 & 0.1667 & 0.0694 & 0.0263 & 0.0132 & 0.0658 & Missing Data & 0.0000 & 0.0549 & 0.0864 & 0.1059 & 0.056 \\
\hline Tabouk & 0.0323 & 0.0323 & 0.0299 & 0.0299 & 0.0299 & 0.0735 & 0.0137 & 0.0274 & 0.1169 & 0.0988 & 0.1325 & 0.056 \\
\hline Hail & 0.0000 & 0.0112 & 0.0215 & 0.0215 & 0.0108 & 0.0833 & 0.0100 & 0.0400 & 0.0476 & 0.0667 & 0.0762 & 0.035 \\
\hline North Boarder & 0.0250 & 0.0256 & 0.0244 & 0.0000 & 0.0000 & 0.2093 & 0.0667 & 0.0667 & 0.0652 & 0.0667 & 0.1277 & 0.062 \\
\hline Jazan & 0.0970 & 0.0597 & 0.0940 & 0.0616 & 0.0068 & 0.1164 & 0.0645 & 0.0258 & 0.0692 & 0.0615 & 0.0730 & 0.066 \\
\hline Najran & 0.0164 & 0.0000 & 0.0161 & 0.1311 & 0.0000 & 0.1475 & 0.0308 & 0.0308 & 0.1029 & 0.1061 & 0.1912 & 0.070 \\
\hline Albaha & 0.0000 & 0.0349 & 0.0549 & 0.0323 & 0.0108 & 0.0510 & 0.0495 & 0.0594 & 0.0588 & 0.0577 & 0.0381 & 0.041 \\
\hline Aljouf & 0.0000 & 0.0357 & 0.0000 & 0.0303 & 0.0303 & 0.1515 & 0.0192 & 0.0286 & 0.0270 & 0.0500 & 0.1190 & 0.045 \\
\hline Alqurayat & 0.3889 & 0.1765 & 0.1000 & 0.0000 & 0.0000 & 0.1250 & Missing Data & 0.0000 & 0.1111 & 0.2000 & 0.1579 & 0.114 \\
\hline Qunfetha & 0.0690 & 0.0690 & 0.0000 & 0.0625 & 0.0313 & 0.0303 & Missing Data & 0.0000 & 0.0270 & 0.0811 & 0.1622 & 0.048 \\
\hline TOTAL & 0.0681 & 0.1096 & 0.0804 & 0.0435 & 0.0086 & 0.1038 & 0.0606 & 0.0726 & 0.1429 & 2.5693 & 3.16585 & 0.077 \\
\hline Average per city & 0.067 & 0.089 & 0.056 & 0.042 & 0.011 & 0.104 & 0.029 & 0.045 & 0.114 & 0.128 & 0.158 & \\
\hline
\end{tabular}

Table 3: Total number of PCC pharmacist demand or required.

\begin{tabular}{|c|c|c|c|c|c|c|c|c|c|c|c|c|}
\hline & 2006 & 2007 & 2008 & 2009 & 2010 & 2011 & 2012 & 2013 & 2014 & 2015 & 2016 & Average \\
\hline Riyadh & 1,785 & 1,737 & 1,841 & 1,984 & 1,994 & 1,958 & 2,103 & 2,098 & 1,992 & 1,922 & 2,006 & $1,947.27$ \\
\hline Makkah & 375 & 363 & 332 & 417 & 419 & 417 & 1,771 & 457 & 411 & 409 & 405 & 525.09 \\
\hline Jeddah & 375 & 375 & 400 & 464 & 465 & 464 & Missing Data & 535 & 431 & 431 & 440 & 438.00 \\
\hline Taif & 520 & 520 & 525 & 558 & 560 & 558 & Missing Data & 598 & 603 & 596 & 602 & 564.00 \\
\hline Madina & 669 & 669 & 668 & 714 & 715 & 714 & 767 & 767 & 814 & 804 & 801 & 736.55 \\
\hline Quseen & 709 & 725 & 760 & 755 & 755 & 752 & 795 & 792 & 847 & 854 & 880 & 784.00 \\
\hline East Province & 555 & 558 & 618 & 612 & 617 & 625 & 1,235 & 674 & 670 & 676 & 675 & 683.18 \\
\hline Alhasa & 285 & 285 & 340 & 315 & 315 & 319 & Missing Data & 355 & 370 & 360 & 344 & 328.80 \\
\hline Heralbatin & 145 & 160 & 170 & 190 & 190 & 188 & Missing Data & 205 & 178 & 199 & 198 & 182.30 \\
\hline Aseer & 1,265 & 1,250 & 1,135 & 1,134 & 1,135 & 1,134 & 1,584 & 1,181 & 1,231 & 1,212 & 1,227 & $1,226.18$ \\
\hline Bisha & 179 & 179 & 358 & 379 & 379 & 379 & Missing Data & 395 & 455 & 402 & 422 & 352.70 \\
\hline Tabouk & 310 & 310 & 335 & 334 & 335 & 339 & 365 & 364 & 380 & 399 & 408 & 352.64 \\
\hline Hail & 440 & 444 & 465 & 465 & 465 & 480 & 500 & 500 & 525 & 525 & 525 & 484.91 \\
\hline North Boarder & 199 & 194 & 204 & 215 & 215 & 212 & 222 & 222 & 227 & 222 & 231 & 214.82 \\
\hline Jazan & 666 & 670 & 745 & 730 & 730 & 728 & 775 & 774 & 792 & 892 & 886 & 762.55 \\
\hline Najran & 304 & 295 & 310 & 304 & 305 & 303 & 324 & 324 & 339 & 330 & 340 & 316.18 \\
\hline Albaha & 430 & 428 & 453 & 464 & 464 & 490 & 504 & 504 & 509 & 518 & 524 & 480.73 \\
\hline Aljouf & 145 & 140 & 165 & 165 & 165 & 165 & 260 & 175 & 185 & 200 & 210 & 179.55 \\
\hline Alqurayat & 85 & 83 & 100 & 80 & 80 & 80 & Missing Data & 85 & 89 & 74 & 94 & 85.00 \\
\hline Qunfetha & 145 & 145 & 150 & 159 & 160 & 165 & Missing Data & 175 & 185 & 184 & 183 & 165.10 \\
\hline TOTAL & 9,586 & 9,530 & 10,074 & 10,438 & 10,463 & 10,470 & 11,205 & 11,180 & 11,233 & 11,209 & 11,401 & $10,617.18$ \\
\hline Average per city & 479.30 & 476.50 & 503.70 & 521.90 & 523.15 & 523.50 & 861.92 & 559.00 & 561.65 & 560.45 & 570.05 & 558.28 \\
\hline
\end{tabular}




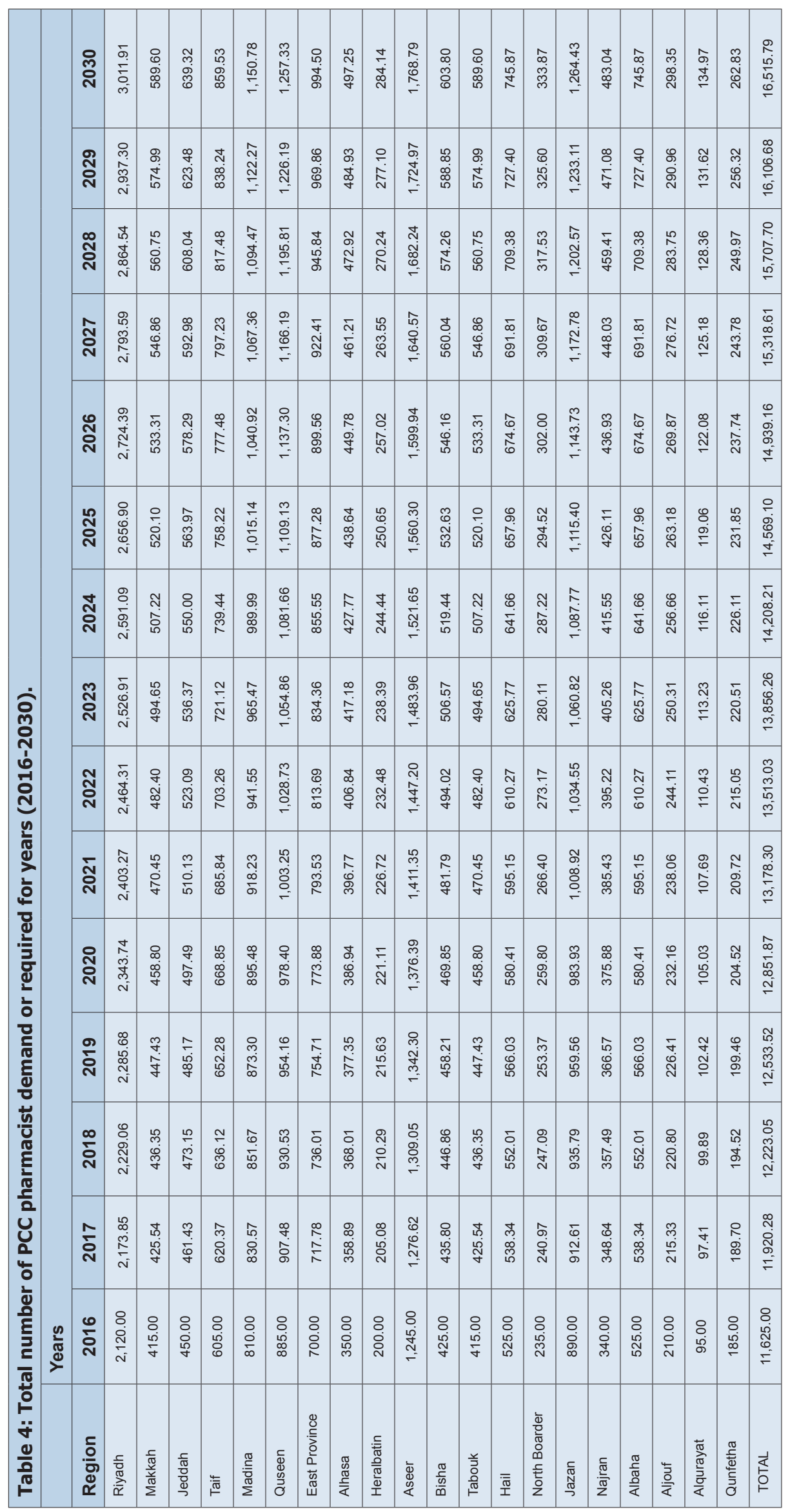


pharmacy practice, this will decrease the burden on all governmental primary care centers. Also, the new vision of pharmacy practice walked toward ambulatory care pharmacy services leads to open number of community pharmacies and more number of pharmacist jobs available in the future.

\section{CONCLUSION}

There is high demand for a number of primary care pharmacists in Kingdom of Saudi Arabia. The implementation of the new vision of pharmacy practice during new Saudi Vision 2030 is required. A new model of Saudi Managed Care Pharmacy is appropriate solution to meet the demand of pharmacist currently and in the future.

\section{ACKNOWLEDGEMENT}

None

\section{CONFLICT OF INTEREST}

None

\section{ABBREVIATION USED}

KSA: Kingdom of Saudi Arabia; MOH: Ministry of Health;

\section{REFERENCES}

1. Kimberly A. Galt, Richard F. Demers RNH. ASHP statement on the pharmacist's role in primary care. Am J Heal Pharm. 1999;56(16):1665-7.

2. Alomi YA. National Primary Care Pharmacist Competency System at $\mathrm{MOH}$ in Saudi Arabia. J Pharm Pharm Sci. 2016;1(4):1-5

3. The Saudi Central Board For Accreditation of Healthcare Institutions (CBAHI). Primary Healthcare Accreditation Standards. 2011;1-135 p.

4. Mcleod DC. Contrast in Pharmacy Manpower Planning between the United States and Northen European Countries. Drug Intell Clin Pharm. 1986;20:210-2.

5. HRSA. A study of the supply and demand for pharmacists [Internet]. Department of Health and Human Services. 2000. p. 100. Available from: www.fip.org/ humanresource.

6. Bond CA, Raehl CL, Patry R. Evidence-based core clinical pharmacy services in United States hospitals in 2020: services and staffing. Pharmacotherapy. 2004;24(4):427-40.

7. Bond CA, Raehl CL. Clinical pharmacy services, pharmacy staffing, and adverse drug reactions in United States hospitals. Pharmacotherapy. 2006;26(6):735-47.

8. Bond CA, Raehl CL. Clinical pharmacy services, pharmacy staffing, and hospital mortality rates. Pharmacotherapy. 2007;27(4):481-93.

9. Hawthorne N, Anderson $\mathrm{C}$. The global pharmacy workforce: A systematic review of the literature. Hum Resour Health. 2009;7(1):48.

10. Gal D, Bates I. 2012 FIP Global Pharmacy Workforce Report [Internet]. 2012. Available from: www.fip.org/humanresource.

11. Workforce H. Pharmacist Workforce. 2012. — Provincial / Territorial Highlights. 2012.

12. Health Workforce Australia. Australia's Health Workforce Series: Pharmacists in Focus. 2014:1-47.
13. Gaither CA, Schommer JC, Doucette WR, Kreling DH, Mott DA. 2014. National Pharmacist Workforce Survey. Workforce. 2015. Available from: http://www. pharmacy.wsu.edu/information/2009.Pharmacist.Workforce.Survey.pdf

14. Robinson E, Shcherbakova N. Assessment of Pharmacy Manpower and Services in New England. J Pharm Pract. 2016;29(6):549-55.

15. Pedersen CA, Schneider PJ, Scheckelhoff DJ. ASHP national survey of pharmacy practice in hospital settings: Dispensing and administration - 2014. Am J Heal Pharm. 2015;72(13):1119-37.

16. Knapp DA. Professionally determined need for pharmacy services in 2020 . Am J Pharm Edu. 2002;66(4):421-9.

17. Health Statistical Year Book 2006. Saudi Ministry of Health. Available from: http:// www.moh.gov.sa/en/Ministry/Statistics/book/Pages/default.aspx.

18. Health Statistical Year Book 2007. Saudi Ministry of Health. Available from: http:// www.moh.gov.sa/en/Ministry/Statistics/book/Pages/default.aspx.

19. Health Statistical Year Book 2008. Saudi Ministry of Health. Available from: http:// www.moh.gov.sa/en/Ministry/Statistics/book/Pages/default.aspx.

20. Health Statistical Year Book 2009. Saudi Ministry of Health. Available from: http:// www.moh.gov.sa/en/Ministry/Statistics/book/Pages/default.aspx.

21. Health Statistical Year Book 2010. Saudi Ministry of Health. Available from: http:// www.moh.gov.sa/en/Ministry/Statistics/book/Pages/default.aspx.

22. Health Statistical Year Book 2011. Saudi Ministry of Health. Available from: http:// www.moh.gov.sa/en/Ministry/Statistics/book/Pages/default.aspx.

23. Health Statistical Year Book 2012. Saudi Ministry of Health. Available from: http:// www.moh.gov.sa/en/Ministry/Statistics/book/Pages/default.aspx.

24. Health Statistical Year Book 2013. Saudi Ministry of Health. Available from: http:// www.moh.gov.sa/en/Ministry/Statistics/book/Pages/default.aspx.

25. Health Statistical Year Book 2014. Saudi Ministry of Health. Available from: http:// www.moh.gov.sa/en/Ministry/Statistics/book/Pages/default.aspx.

26. Health Statistical Year Book 2015. Saudi Ministry of Health. Available from: http:// www.moh.gov.sa/en/Ministry/Statistics/book/Pages/default.aspx.

27. Health Statistical Year Book 2016. Saudi Ministry of Health. Available from: http:// www.moh.gov.sa/en/Ministry/Statistics/book/Pages/default.aspx.

28. American Society of Hospital Pharmacists. ASHP Statement on Pharmaceutical Care. Am J Hosp Pharm. 1993;50:1720-3.

29. American Society of Hospital Pharmacists. ASHP Guidelines on a Standardized Method for Pharmaceutical Care. Am Soc Heal Pharm. 1996;53(14):1713-6.

30. Medication Management (MM). In: National Hospital Standards. 2nd Ed. Saudi Central Board for Accreditation of Healthcare Institutions. 2015;194-211. Available from: http://www.cbahi.gov.sa.

31. The Joint Commission. Comprehensive Accreditation Manuals. Joint Commission Resources. Available from: http://www.jcrinc.com/store/publications/manuals/.

32. Alomi YA, Alghamdi SJ, Alattyh RA. Strategic Plan of General Administration of Pharmaceutical Care at Ministry of Health in Saudi Arabia 2012-2022. J Pharm Pharm Scien. 2015;1(3):1-8.

33. Alomi YA. National Pharmacy Practice Programs at Ministry of Health in Saudi Arabia. JPharm Pharm Scien. 2015;1(2):17-8.

34. Alomi YA. National Pharmacy Administration Programs at Ministry of Health in Saudi Arabia. BAOJ Pharm Sci. 2015;1(9).

35. Alomi YA. Primary Care Center Pharmacy Manpower New Guidelines in Saudi Arabia. J Pharmacol Clin Res. 2016;1(1).

Cite this article as: Alomi YA, Alghamdi SJ, Alattyh RA. Primary Care Centers Pharmacist Workforce Demand in Eleven Years (2006-2016), and Forecasting in Fifteen Years (2016-2030) at Ministry of Health in Saudi Arabia. J Pharm Pract Community Med. 2018;4(1s):S121-S5. 